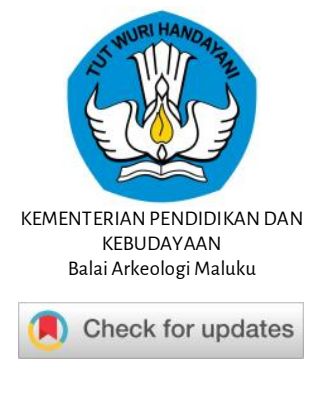

Kapata Arkeologi, 15(1) 2019, 15-24

p-ISSN: 1858-4101, e-ISSN: 2503-0876

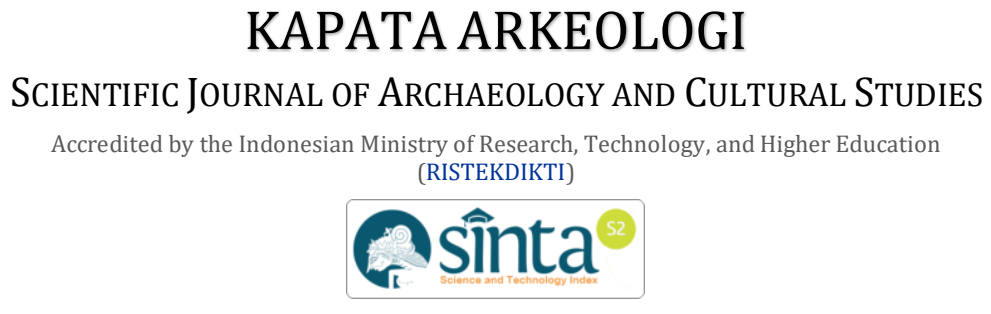

http://kapata-arkeologi.kemdikbud.go.id/

\title{
Cultural Heritage Digitization in Indonesia: A NeW Perspective on Preserving Depok Colonial Heritage
}

\author{
Alqiz Lukman (D) 1 *, Ghilman Assilmi (D) 2 , Ide Nada Imandiharja (D) 2 \\ ${ }^{1}$ Pusat Penelitian Arkeologi Nasional \\ Jl. Raya Condet Pejaten No. 4, Jakarta 12510, Indonesia \\ ${ }^{2}$ Department of Archaeology, Faculty of Humanities, Universitas Indonesia \\ Kampus UI, Depok 16424, Indonesia \\ * alqiz.lukman@gmail.com
}

Received: 07/09/2018; revisions: 09/11 — 07/01/2019; accepted: 08/01/2019

Published online: 31/07/2019

\begin{abstract}
New technologies, such as digital photography, 3D scanner, and augmented reality, provide an alternative to preserve heritage sites. The focal point for this article is to continue the discourse on the advantages of digital preservation based on our work in Depok, called Depok Lama Project. Depok is a city located in West Java Province that has many colonial buildings, such as residential settlements, churches, and bridges. However, a recent study shows almost $75 \%$ of colonial buildings have been demolished over the last decade due to city development and rapid modernization. We created a project to digitize the cultural heritage in Depok to prevent further destruction and encourage the importance of the buildings to the public through digital media. This project is a multidisciplinary project that involved archaeologists, historians, IT experts, and the local community in creating an interactive system database regarding heritage buildings in Depok. Four studies were carried out to develop the Depok Lama Project, namely content information study, end-user perspective study, website design framework construction, and evaluation study. The first study was used to collect information regarding the historical buildings at the Old Depok. The second study was conducted to investigate the information presentation preferred by the end-users. The third study concerned the development of a website prototype based on data from previous studies. The final study was to evaluate and enhance the website prototype. The results show that the cultural heritage digitization is not only useful for preservation but also for public engagement and facilitate cultural learning.
\end{abstract}

Keywords: Digital Heritage; Heritage Preservation; Cultural Learning; Community Engagement; Depok

\section{INTRODUCTION}

There is no doubt that cultural heritage across the world threatened by modernization. The pressures for development have made modernization a priority in many countries, including Indonesia. Many modernization projects, such as building telecommunication and transportation infrastructure, are often planned without paying any attention to or having a proper assessment of the historical landscape (Hosagrahar, 2015: 118). As a consequence, the destruction of the authenticity of heritage occurs in many cases. A recent example is the nomination of Old Town of Jakarta for inscription on the UNESCO world heritage list. ICOMOS examination of the Old Town of Jakarta dossier shows current, and further urban development planning in the area had transformed the landscape of the sites. Thus, it affected to deterioration of the area's integrity and authenticity (ICOMOS, 2018: 95-96). The result of the ICOMOS evaluation of Old Town of Jakarta causes the Indonesian government to withdraw the dossier from UNESCO.

In the case of Depok, a study from Yayasan Lembaga Cornelis Chastelein or Cornelis Chastelein Foundation (hereafter YLCC), an independent foundation who deal with history and heritage in Depok, shows almost $75 \%$ of historic buildings has been demolished for new residences and other commercial buildings purpose (Arifianto, 2017). Institutional lack of capacity to manage a range of issues related to the cultural impact of modernization projects is one of the significant challenges that has threatened cultural heritage in Depok. Unfortunately, this happened to Depok although this city was a particuliere landerijen or private estate owned by Cornelis Chastelein, an extraordinary member of the Raad van Indie, in the $17^{\text {th }}$ century $\mathrm{AD}$. The uniqueness of Depok under Chastelein's rule was he taught his 


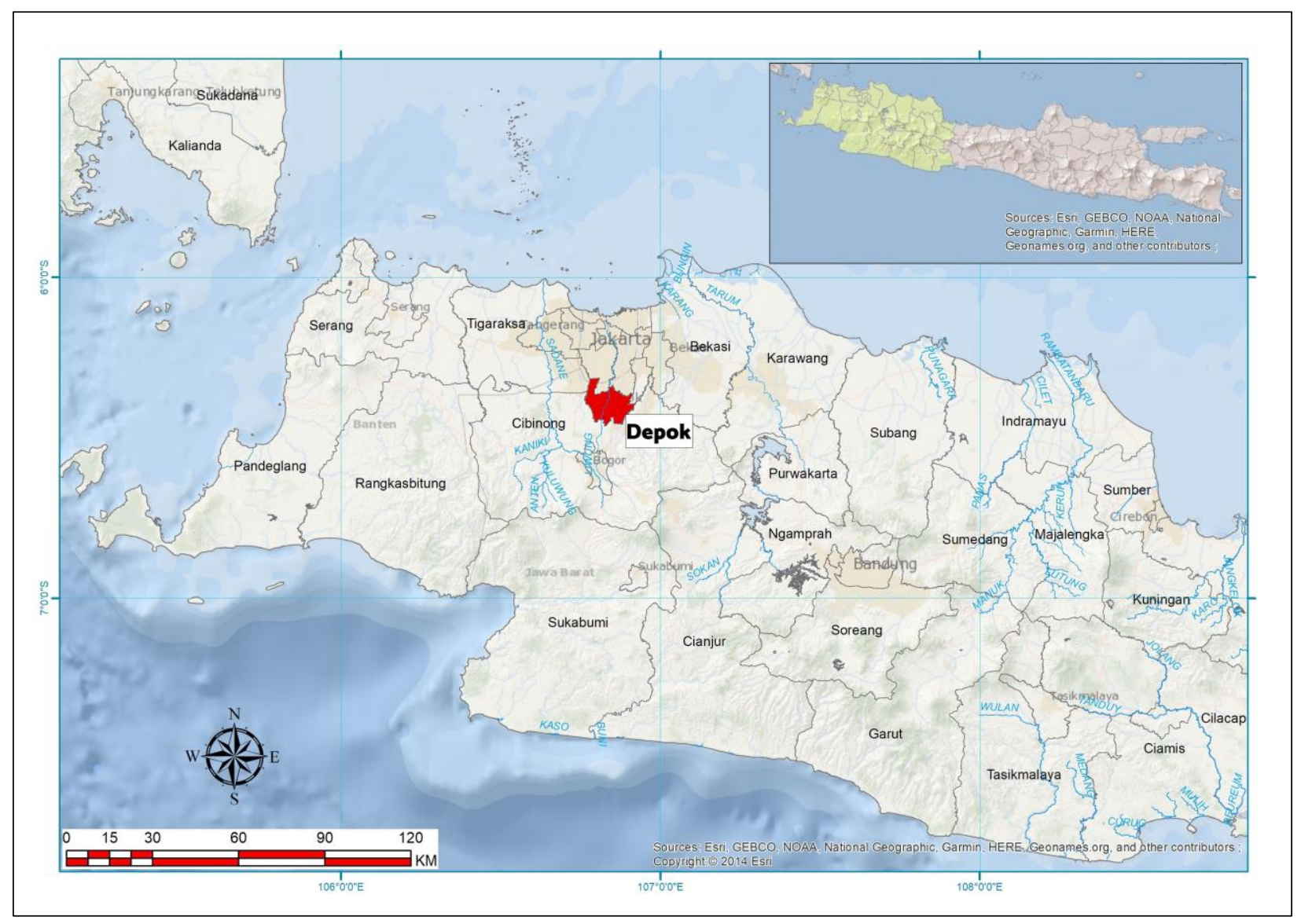

Figure 1. Map of Depok Location

(Source: ArcGIS Database, 2018)

slaves of Christianity and freeing them from illiteracy. It because he criticized the VOC for always concerning their commercial interests without prospering people in the colony. Several scholars noted he succeeded in making Depok a productive example of a colony city without persecution (Irsyam, 2017: 42; Jonathans, 2011: 35; Kanumoyoso, 2011: 88). He also successfully integrates his slaves into Dutch society in Indonesia. How the slaves speak, act, and dress up as same as the Dutch people. The Chastelein slaves then continued to manage the land and became the embryo of modern Depok. Meanwhile, most people globally are frequent users of digital technologies such as computer games, mobile phones, and television. Furthermore, this habit is predicted not to change much in the near future (Rodil \& Winschiers-Theophilus, 2018: 144). In an attempt to bridge the public, technology, and preservation, we see the digitization of cultural heritage as a plausible way to safeguarding heritage in Depok. The utilization of computer technology for heritage preservation purpose that replicates visualizes or simulates is called digital heritage (Y. E. Kalay, 2007: 6-8). Another way to defining the concept of digital heritage preservation is computer-generated materials of heritage value that should keep for the future generation. UNESCO also made a charter on the digital heritage preservation to ensure public accessibility, to prevent a threat to being lost for posterity, and digital continuity in the long-term (UNESCO, 2003).

In Indonesia, digitization is essential for documenting the national cultural wealth because current documentation process is still inadequate and not wellstructured (Tanaamah \& Wenas, 2014: 125-126). Academicians and heritage practitioners in Indonesia are started using digital media for preservation, communication, and research of cultural heritage. In 2014, the Universitas Indonesia in collaboration with Balai Pelestarian Cagar Budaya Jambi (BPCB Jambi) create a digital database of pottery and ceramics from Muarajambi Temple that open to the public (Pojoh, Sulistyowati, Nugraha, \& Caesario, 2015). Tanaamah and Wenas made a digital repository of tangible and intangible heritage at Kasunanan Surakarta Palace (Tanaamah \& Wenas, 2014). Melkior Sitokdana (2015: 107-108) in his research stated that cultural heritage digitization could be benefited to the knowledge management system, tourism and business, government regulation, and education. Furthermore, digitization also supports protection, development, and utilization of heritage under the mandate of the Cultural Heritage Act No. 11/2010 and Cultural Advancement Act No. 5/2017.

Kasper Rodil and Matthias Rehm (2015: 50) stated that digital technology would greatly benefit to the preservation of cultural heritage and more inclusion of 
public. However, some considerations need to be taken into account when incorporating heritage values and information in digital media. How to make the end-users aware of its heritage significance? How to determine cultural information to be included and discarded on the website? How to construct efficient narratives to facilitate cultural learning? Those are questions that need to deliberate while working on digital heritage. Therefore, we see a strong reason to evaluate the processes, effects, and outcomes of turning heritage digital.

Several studies have proposed essential aspects for designing virtual heritage environments that facilitate cultural learning. An interactive presentation should be suitable for learning that appealing, enjoyable, engaging, and allow users to explore by themselves. To form a well digital environment (website) as informal education media that leads to historical and cultural awareness among users involves four essential factors, namely information content related, environment setting, user interface, and user experience (Abubakar, Jahnkassim, \& Mahmud, 2013: 5-6; Ibrahim \& Ali, 2018: 5; Tanaamah \& Wenas, 2014: 131-132). By acknowledge those four elements, the presentation of heritage information and its embodied interaction will evoke end-users awareness of heritage conservation. Thus, the objective of this paper is to demonstrate the use of digital technology for heritage preservation while at the same time facilitate cultural learning that affects the end user's sense of awareness and appreciation toward heritage values.

The focal point for this article is to continue the discourse on the advantages of digital preservation. In this article, we present a case study of our work in Depok called Depok Lama Project. The website can access through www.depoklamaproject.com. All of the information contained in the website is in Bahasa, Indonesia. We created this project to digitize the cultural heritage in Depok to prevent further destruction and encourage the importance of the buildings to the public through digital media. This project is a multidisciplinary project that involved archaeologists, historians, IT experts, and the local community in creating an interactive system database regarding heritage buildings in Depok. By using digital technology for heritage preservation, this paper argued it also could facilitate cultural learning that affected the end user's sense of awareness and appreciation toward heritage values and its significances.

\section{Methods}

Four studies were carried out to develop the Depok Lama Project, namely content information study, enduser perspective study, website design framework construction, and evaluation studies (Figure 2). The methods we used based on the Virtual Heritage
Environment framework (Ibrahim \& Ali, 2018). The original framework has divided the study into five phases, namely content requirement study (heritage expert perspective), content requirement study (end-user perspective), design framework construction, expert review, and evaluation study. We merge the expert review to evaluation study because the heritage expert that review our website also our participants for the evaluation study.

The first study was used to collect information regarding the history, collective memory, and other related information regarding historical buildings at the Old Depok. We conducted interviews in the first study with nine people who represented the major parties involved and affected by the heritage of Depok. Our informants included YLCC, local elders, the descendants of Chastelein's slave, heritage experts, and historians. The interview was used to gain insights and a more indepth understanding of the multiple perspectives and factors that contribute to our content information development. In this way, our interpretation can be checked, reinterpreted, and evaluated by various actors (Mutema, 2003: 5). Also, we conducted a literature survey and collected old pictures and old maps to grasp the bigger picture of historical buildings in Depok.

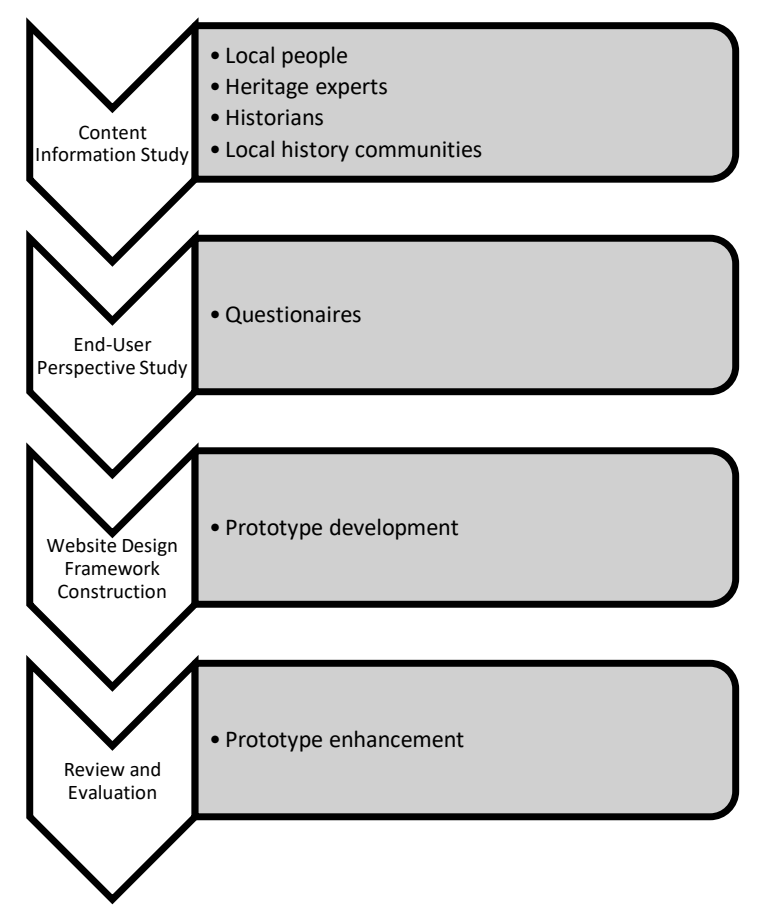

Figure 2. The overall studies of Depok Lama Project (Source: Authors, 2018)

The second study was conducted to investigate the information presentation preferred by the end-users. It also prevents overwhelming information and unattractive design. Semi-structured interviews with open-ended questions were used to know participants' perspective on what kind of information they would like to see on the website. The total number of participants 


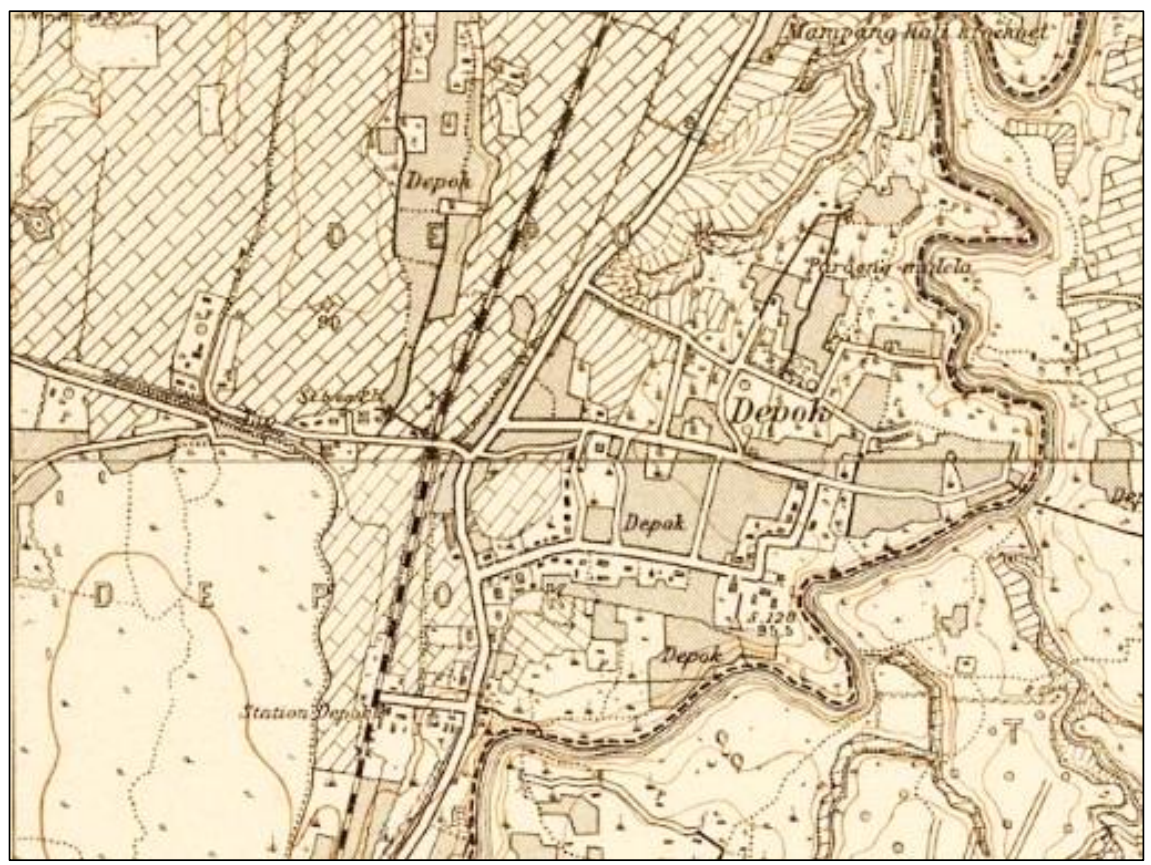

Figure 3. Map of Depok in 1904

(Source: KITLV Maps, accessed on $30^{\text {th }}$ August 2018)

was 28 respondents (17 males and 11 females) aged between 18-34. All of the participants use the computer and are familiar with the internet and digital information. All the participants live in Depok. Thirteen regularly, participants have a background in either archaeology or history. We realized that this number of participants could not represent the voice of Depok Society. We conducted this study with a small number of participants to be able in-depth analysis, and it is difficult to find a dedicated respondent who is willing to spend a considerable amount of time considering this program runs within a year.

The third study concerned the development of a website prototype based on data from previous studies. The scope of the development focused on five elements of conducive virtual heritage environment that we already discussed in the introduction. We also collaborated with IT experts, visual designer, and marketing experts in the process of development.

The objective of the final study was to avoid possible issues and to provide gain suggestions to improve the framework and the quantitative method used with closed-ended questions to systematically measure the usefulness of factors. The participants for this study were the same people from a prior study with five additional participants. Thus, they had experienced in the beginning process, which made it easier to use for them to analyze information from the website. The refined framework reevaluated and finalized based on feedback given by our respondents. State the objectives of the work and provide an adequate background, avoiding a detailed literature survey or a summary of the results.

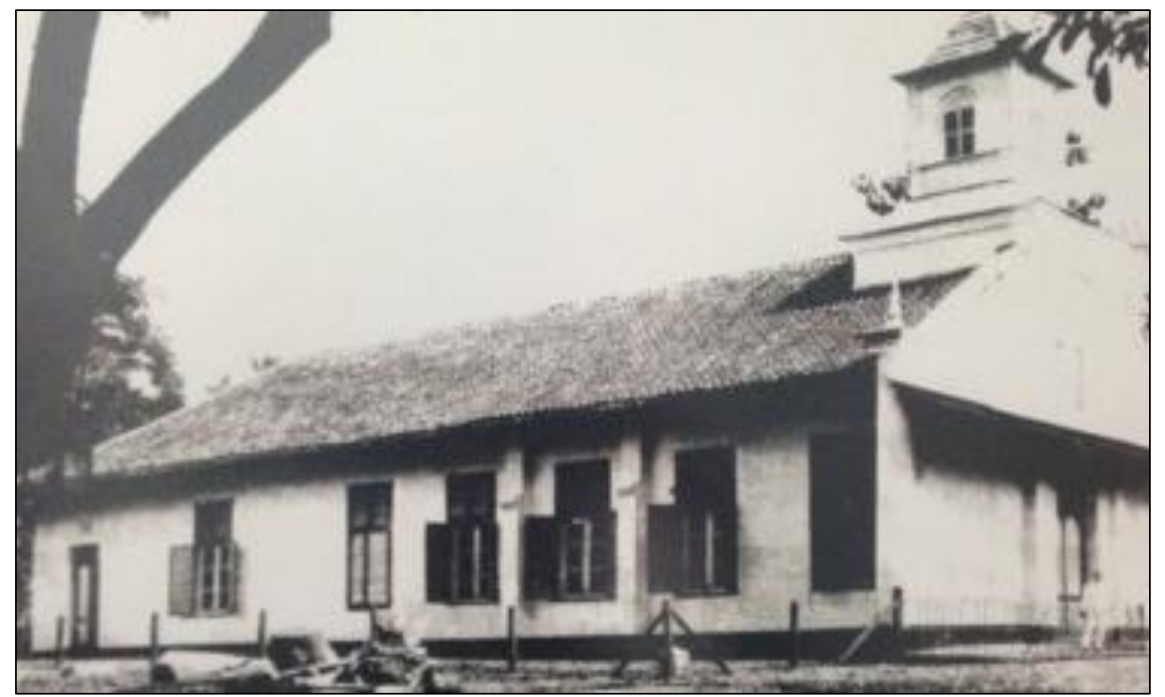

Figure 4. GPIB Immanuel Church (source: YLCC Archive) 


\section{RESULT AND DISCUSSION}

In the 17th century AD, Depok was a plantation area owned by a high ranked VOC, Cornelis Chastelein (Irsyam, 2017: 39-43). He brought more than a hundred slaves to work on his land in Depok from all over Nusantara, particularly from Bali, Makassar, Maluku, Java, and Rote Island. Nevertheless, unlike other landlords at that time who only concerned their interests, Chastelein taught his slaves Christianity and free them from illiteracy. According to R. M. Jonathans (2011: 3537), in his speech during Depok Festival, Chastelein was treated his slave with compassion and established rules of life that inherited until now. His rules cover seven aspects, namely religion (Christianity); social welfare; social security and protection; economy and trade; democracy; preserve the environment; and literacy. $\mathrm{He}$ did that because he tried to create Depok as a prototype colony area that is fully managed by an indigenous community (Ongirwalu \& Jonathans, 2014: 30-33). At the end of his life, Cornelis Chastelein liberated his slaves and gave his land at Depok to them. The Chastelein slaves then continue to manage the land, which became the embryo of modern Depok. Thus, the Chastelein slaves are now known as 'The Old Depok People' or 'Dutch Depok.' The Old Depok people divided into twelve family names, namely Bacas, Isakh, Jonathans, Jacob, Joseph, Loen, Laurens, Leander, Tholense, Soedira, Samuel, and Zadokh. It is not known when the family names were used and who gave the names. Some scholars assumed that they got their family name from Christian priests who adopted these names from the bible. However, Soedira is known as the oldest family name since it is the only name that registered in Chastelein's testament.

In 1871, the Netherland-Indies government gave Depok an autonomy status that allowed the Old Depok People to form their government with the president as the highest leader. The President of Depok assisted by nine foremen, traditional police, and kumitir (who controls plantation production) (Irsyam, 2017: 44). Since 1871 there were five presidents of Depok. During this time, the city center consisted of only four main roads, namely Kerkweg, Pasarstraat, Middenweg, and Kartinistraat. Kerkweg was the main road that lies government buildings, church, and schools (Figure 3). As the name implies, Pasarstraat was the trading center of the city. On the other side of the city center was Middenweg, which connected Depok with Batavia and Buitenzorg. Kartinistraat was a road that connects the city to the railway station. Today, this area is known as 'Depok Lama' or Old Depok.

After the independence of Indonesia in 1945, Depok became the NICA military base. In 1952, Depok was nationalized and became part of the Republic of
Indonesia. Most of the street names were also nationalized, as Kerkweg became Jalan Pemuda, Pasarstraat became Jalan Dewi Sartika, and Middenweg became Jalan Siliwangi. Only Kartinistraat or Jalan Kartini has not been changing until today. At that time, Depok was a sub-district that covered 21 villages under the Parung Regency jurisdiction. In 1976, a national residence project started in Depokwhich triggered the development of the Depok to become a city in 1982. The city of Depok continued growing into a modern city that we see today.

Based on a brief description of the history of Depok, there must have been many historical buildings that witnessed the development of the city. Along Pemuda Street alone there are many buildings dating from the 18th century $\mathrm{AD}$ to the pre-independence period, such as the GPIB Immanuel Church (see Figure 4), Eben Haezer Building, Dutch schools (now Pancoran Mas 2 Elementary School), Vicarage and Colonial government building (now Harapan Hospital). These buildings are monuments and reminders of the past Depok City as the first Christian city and one of the oldest plantation areas in Indonesia (Prasidha \& Martokusumo, 2014).

Nowadays, unfortunately, some of the remaining buildings have deteriorated and have been demolished due to city development. The local government does not seem to pay attention to the importance of preserving the historical buildings in Depok even though these buildings have an identity, culture, history, and collective memory of the people of Depok. Therefore, we tried to preserve this part of history in a digital form (website) under the Depok Lama Project. The website could access through www.depoklamaproject.com. All of the information contained in the website is in Bahasa, Indonesia.

\section{Inside and Outside Actors}

We argued that the most critical point in digital archaeology involves the participants who actively manage the sites as our main informant. Thus, the first organization we contacted when starting this project was YLCC. We engaged the YLCC because this foundation is organized by the Old Depok people who were actively preserving the legacy of Cornelis Chastelein, such as their land, public buildings (church and vicarage) and school. We want to create a website with stories of historical buildings from local people memories to trigger end-users curiosity. Our initial idea strengthened by the fact that the local community had maintained indigenous traditions and memories throughout the centuries and researchers have to recognize their influences on heritage sites (Murphy, 2014: 8; Rodil \& Winschiers-Theophilus, 2016: 146).

Throughout the interview with a delegation from YLCC, we found a complex problem on the situation of 


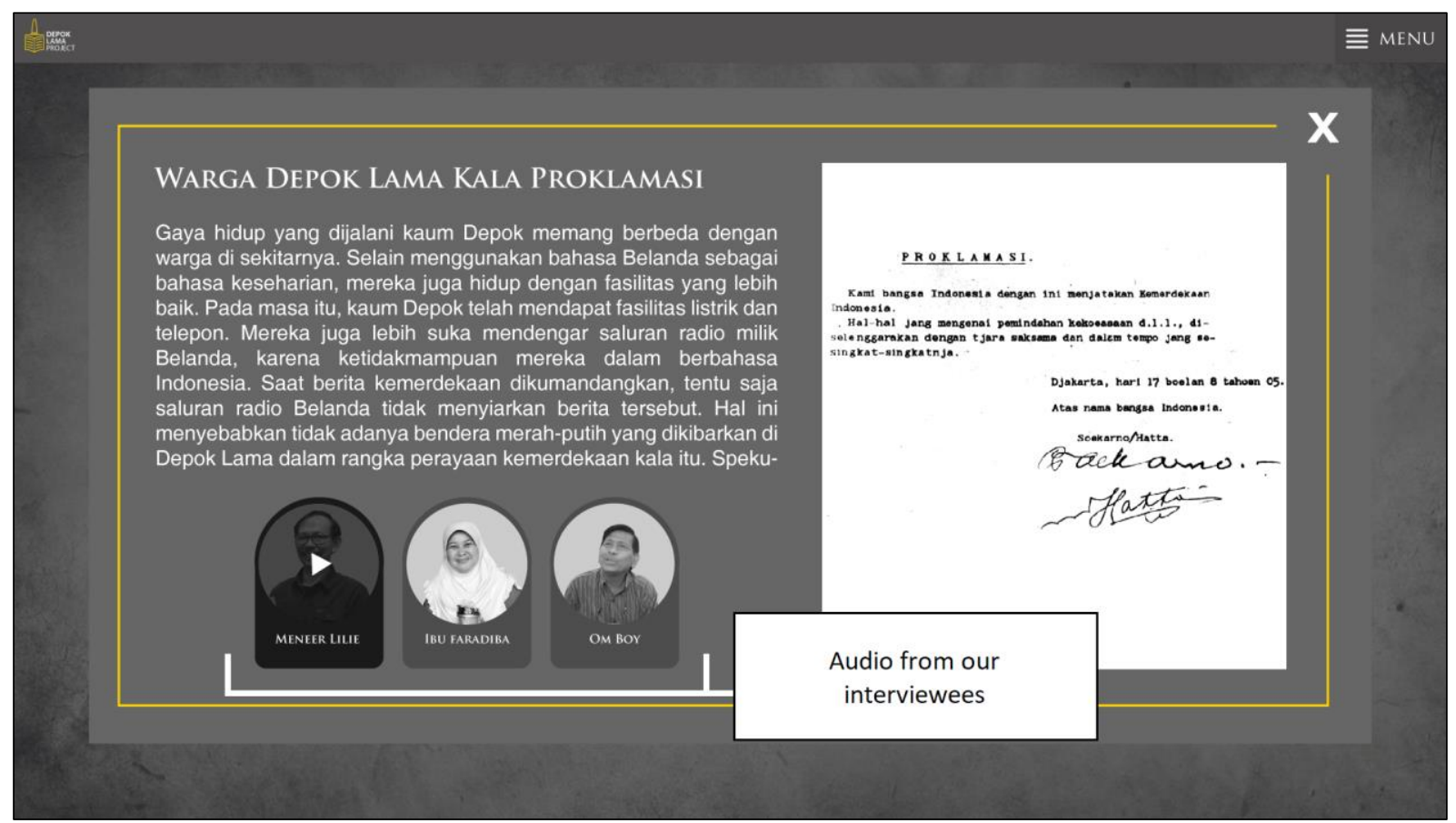

Figure 5. Multivocality in Depok Lama Project

(Source: Authors, 2018)

the current historical buildings. In 2004, the local government had initiated to register the Old Depok area as a cultural heritage. However, the registration is still pending. Because the Old Depok area is a legacy from the Netherlands colonialism, it could create controversies and problems if this area granted cultural heritage status. Thus, the local government is postponing the heritage status of Old Depok area until now.

To prevent rising issues in Depok society when we publish the digitization of historical buildings in Old Depok area to the public, we consulted and interviewed heritage experts, historian, and local community who concerns about the history of Depok to gain more information about this issue. While we interview those parties, we got an idea to create a storytelling website about the history of the Old Depok area from multiple perspectives. Rather than focusing on the story of the building itself, we present the story of how the Old Depok area built and what does it inherit to us. Thus, end-users can understand and evaluate the story that may raise the awareness and appreciation to the historical buildings in Depok.

\section{Website Content Development}

At the early development stage, while considering the initial web-design, selection on the content subject is purposely discussed with our participants and questionnaire respondents in order to get a useful model to propagate the heritage information. Based on the discussions, we are using the interactive digital storytelling models for Depok Lama Project website. There are many definitions of interactive digital storytelling, but in this paper, we define it as a combination of various digital multimedia, such as images, audio, and video to tell users a story (Robin, 2006: 709). By using this model, the content of information should attract a broader audience due to the utilization of various multimedia.

We divided the story of the website into five chapters, namely the etymology of Depok, Depok during Chastelein's period, Depok after the death of Chastelein, Gedoran Depok, and Historical Buildings. The story based on the information derived from our interviewees of the first study. We presented the information from interviewees into audio that users can choose and hear. Thus, the story of each chapter is a combination of insights from various perspectives that allow users to interpret and evaluate by themselves (see Figure 5). All of the information on the website is written in Bahasa Indonesia, because our target users are Indonesian people, especially Depok society.

In order to address structured information to users, our respondents suggested creating a guide sentence to attract user's curiosity and interest in particular topics. When writing the description, we highlighted the main point of what our informants discussed. We wrote the description in short and straightforward text to ensure the attractiveness of the website and to avoid overwhelming information for users. We also put a picture related to the topic with trivia information to enhance users' attention (an example shown in Figure 6).

\section{User Interface and Experience of Depok Lama Project}

The questionnaire was distributed after the group The user interface is defined as the place where interaction between human and computer system happens. The user 


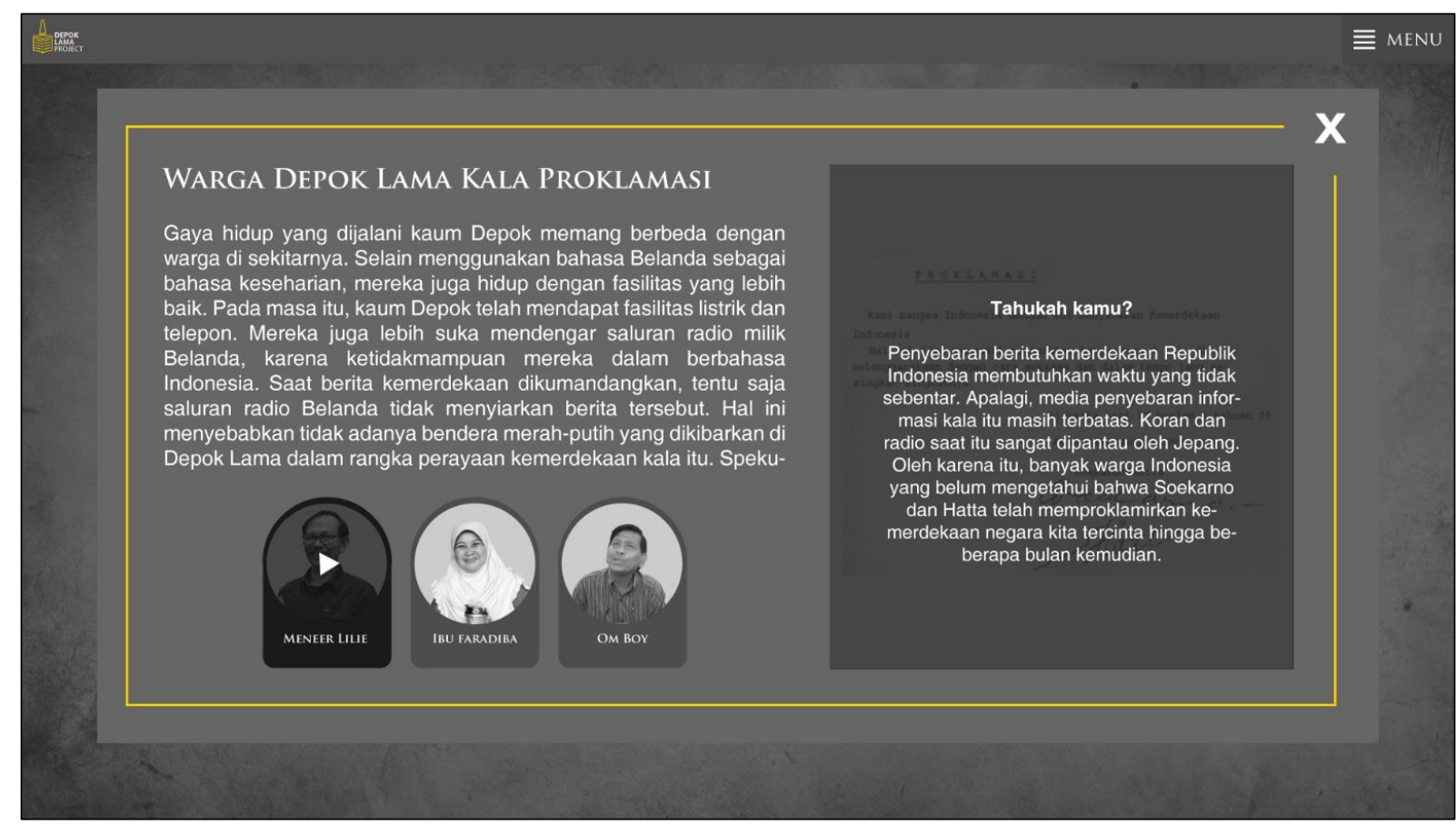

Figure 6. Trivia information appears when the user hovers the picture (Source: Authors, 2018)

interface has a secure connection to user experience. An excellent user interface will satisfy the user while exploring the website. Therefore, in the interface aspects, we collaborated with IT experts, visual designer, and marketing experts to create an explicit navigation instruction that makes users exploring the website more accessible. The selection of font style, color palette, and size of the picture have to be well-calculated in order to produce conducive environment settings. We chose a greyscale palette as a website color scheme to make a vintage atmosphere and suited it with old pictures. The suggestion for font style is the sans serif font that does not have to extend features at the end of strokes. This type of font is more readable on a computer screen and is easier to read for people with dyslexia.

Based on the discussion with our experts, we also added background music songs to play with the user's emotion. Music is well-known as the language of emotions. Background music can affect the user's mood and emotion while absorbing the information from the website (Kim et al., 2010: 256-258). A sad song was used in the story of the deterioration of historical buildings while adventure music used on the page of Cornelis Chastelein migrate from the Netherlands to Batavia.

The early design stage puts interviewees insight into a particular theme into text that users can click using icons to reveal the information. In the second study on the end-user perspective, we tested the prototype on our participants. The designated tasks were navigating through the website and reading the contained information. They have the option to ignore the information or to stop whenever they want. The feedback from the participants stated that the website feels hollow and quite dull. Then, we put the original audio of the interview to change the information texts.

Interestingly, the participants gave positive feedbacks and more curious to discover more on the website. The participants can feel the emotion of interviewees when they told their stories to make them excited. It perhaps explains the necessity of using multisensory digital media to keep users interested when exploring the website (Robin, 2006). Thus, we decided to use the audio recording for the interviewee's explanation. From this experiment, we learned that we have to maximize the user's senses in the form of music, audio recording, pictures, and other visual design to increase users' interest in exploring the website. The biggest challenge when designing the storytelling website is not just how to make the audiences learn, but also how to motivate them to learn.

\section{End-Users Evaluation}

The newly enhanced prototype was used in the evaluation by the end-user participants (Study 4). The designated tasks were the same as Study 2, with additional questions of what they had learned from the website. From the results, we observed that all participants had learned something from the website. They were curious to learn more and feeling excited about the new information gained. We presumed that the participants wanted to learn the information on the website because it needs active participation from participants. They can reinterpret, reach conclusions, and increase their understanding by themselves while exploring the website. It is in line with Hein's statement that learning is an active process which requires the learners to interact 'minds-on' and 'hands-on' (with the 
materials); learning is the process of grappling new information and not only absorbing it (Hein, 1998: 345346). Besides, active learning recognizes that in order to learn, the learner's active participation is required.

The most exciting findings in this evaluation are around $70 \%$ ( 28 persons) of the participants wanted to visit the actual area to have physical interaction with the Old Depok area. Almost 10\% (10 persons) of participants already visited the site after the previous experiment (Study 2). They also started asking why is there no signage or information board, why the buildings look dirty, and why the government did not pay attention to conserve the buildings. In this sense, the website evoked the participants' awareness of historical building in Depok. It opens up more opportunities to engage the public in the actual heritage preservation process in Depok. If the public actively participates in the preservation of the Old Depok area, the local government does not have a reason to postpone its heritage status.

\section{The Benefit of Cultural Heritage Digitization}

In the previous section, have described the digitizing project of cultural heritage in Depok. Many advantages can obtain by implementing cultural heritage digitization in other sites in Indonesia as it provides solutions to heritage management in Indonesia. In this section, we would like to emphasize three benefits of using cultural heritage digitization.

Firstly, the digitizing of cultural heritage provides an alternative to preserve heritage sites. It can retain more data in digital format, while at the same time reducing the physical cost and storage. When preserving cultural heritage, it is not only focused on recovering the sites or structure but also the collective memory of local people that carry identity and meaning (Malpas, 2007: 16). The inter-relation of person and 'material stuff' made cultural heritage is formed and maintained. As in the case of Depok Lama Project, we recorded the memory of local people, academicians, and heritage activists in digital format. By using digital format, we can record and updated the information from time to time in an integrated database that minimizes data confusion. It is in line with Pojoh et al. statement (2015: 78-79) that digital database facilitates data collection in terms of time efficiency and the sustainability of information repository.

Secondly, digital heritage is useful for public engagement. According to the UNESCO World Heritage Convention and the Cultural Heritage Act No. 11/2010, everyone has the right to participate and enjoy freedom in the creation of cultural heritage. In Indonesia, public participation related to heritage preservation still faced many challenges. When it comes to preserving and disseminating scientific knowledge and cultural heritage, decision making tends to delegated to government, academicians, or heritage experts (Hampton, 2005: 742743; Lukman, 2017: 25). The majority of society is intended only to be informed about the decisions made and is not required to give an opinion as well as participation. Digital technologies and the internet bring opportunities to reach broader audiences and engage new user experiences and reusing it to develop learning and educational content, as shown in the Depok Lama Project.

Lastly, cultural heritage digitization can facilitate cultural learning. Digital heritage is providing space, time, and perspectives in order to grapple the heritage issue. In the case of Depok Lama Project, the website provides a window of memories from various perspectives with a diverse set of values and beliefs related to cultural heritage in Depok. Furthermore, by incorporates digital interactivity and multimedia representations, it offers 'a scene' through time and space that are qualitatively different from what may be possible using traditional media and narratives that improve communication with the user (Dave, 2007: 4849). The designated information in the website attract users' attention and engage them to be interested in exploring further. Then, it allows people to make meaningful connections with the historic building in Depok and, in the end, it evoked the participants' awareness and appreciation to that heritage as reflected in the end-user evaluation.

\section{CONCLUSION}

In this article, we attempt to demonstrate that cultural heritage digitization can also facilitate cultural learning. In the development of the website, four essential factors considered, namely information content related, environment setting, user interface, and user experience. We also examine those four factors in a more general context with end-users. For example, navigation aids, multimedia information, background music, and color palettes. This project considered a preliminary study, and further research is still necessary for these four factors of cultural heritage digitization.

We have learned that cultural heritage digitization is not only beneficial for preservation but also useful to engage the public. Besides, the storytelling website is not merely giving knowledge to the users, but it also provides a setting that provokes users to discover and create meaningful connections with the heritage that leads to cultural awareness and appreciation. Hopefully, this sense of awareness and appreciation of the heritage should encourage their desires to protect and preserve the buildings.

This phenomenon creates a new opportunity to expand the potential of digital media not only for heritage preservation but also for community involvement. In order to address public interests, heritage practitioner needs to implement new mobile 
technologies, which can combine the entertainment of digital technology such as video games to learn about heritage. The emergence of new research on digital heritage is an initiative that should be emerged and welcomed by heritage practitioner and archaeologists in Indonesia.

\section{ACKNOWLEDGEMENT}

This research funded by the Community Engagement Grant from the Faculty of Humanities, Universitas Indonesia. We want to acknowledge Danang Aryo Nugroho, Khaesyar Nisfhan, Muhammad Jazmi, Fathya Afifa, and Muhammad Sabiq for helping us in the development of the Depok Lama Project.

$* * * * *$

\section{REFERENCES}

Abubakar, J. A., Jahnkassim, P. S., \& Mahmud, M. (2013). User Requirements for Architectural Heritage Learning through Virtual Reality. International Journal of Interactive Digital Media, 1, 1-9.

ArcGIS Database. (2018). GEBCO 2018 Basemap (NOAA NCEI Visualization). Retrieved November 12, 2018, from http://hub.arcgis.com/

Arifianto, B. (2017). Tak Jadi Tujuan Wisata Sejarah, Bangunan Tua di Depok Lama Banyak Beralih Fungsi. Pikiran Rakyat. Retrieved October 5, 2017, from http://www.pikiran-rakyat.com

Dave, B. (2007). Virtual Heritage: Mediating space, time and perspectives. In Y. E. Kalay, T. Kvan, \& J. Affleck (Eds.) New Heritage: New Media and Cultural Heritage (pp. 40-52). New York: Routledge.

Hampton, M. P. (2005). Heritage, Local Communities, and Economic Development. Annals of Tourism Research, 32(3), 735-759.

Hein, G. E. (1998). Learning in the Museum. New York: Routledge.

Hosagrahar, J. (2015). Urban Heritage and Sustainable Development in South Asia: A Plea for a Heritage-Aware Approach. In M. T. Albert (Ed.), Perception of Sustainability in Heritage Studies (pp. 113-124). Berlin: De Gruyter.

Ibrahim, N., \& Ali, N. M. (2018). A Conceptual Framework for Designing Virtual Heritage Environment for Cultural Learning. Journal on Computing and Cultural Heritage, 11(2), 1-27.

ICOMOS. (2018). Evaluation of Nominations of Cultural and Mixed Properties 2018: ICOMOS report for the World Heritage Committee 42nd ordinary session, Manama, 24 June-4 July 2018. Paris: ICOMOS.

Irsyam, T. W. M. (2017). Berkembang dalam bayang-bayang Jakarta: Sejarah Depok 1950-1990-an. Jakarta: Yayasan Pustaka Obor Indonesia.

Jonathans, Y. (2011). Depok Tempo Doeloe: Potret Kehidupan Sosial dan Budaya Masyarakat. Jakarta: Libri.
Kalay, Y. E. (2007). Preserving Cultural Heritage through Digital Media. In Y. E. Kalay, T. Kvan, \& J. Affleck (Eds.), New Heritage: New Media and Cultural Heritage (pp. 1-10). New York: Routledge.

Kanumoyoso, B. (2011). Beyond the city wall: Society and economic development in the Ommelanden of Batavia, 1684-1740. Leiden: Universiteit Leiden.

Kim, Y. E., Schmidt, E. M., Migneco, R., Morton, B. G., Richardson, P., Scott, J., ... \& Turnbull, D. (2010). Music Emotion Recognition: A State of the Art Review. In The 11th International Society for Music Information Retrieval Conference (ISMIR 2010) (pp. 255-266). Utrecht: Universiteit Utrecht.

KITLV Maps. Atlas van Nederlandsch Oost-Indië [cartographic material] / bij het Topographisch Bureau te Batavia samengesteld in de jaren 1897-1904. Retrieved August 30, 2018, from https://universiteitleiden.nl/

Lukman, A. (2017). Sustainable Development and Cultural Heritage Management: The Case Study of the Community-based Underwater Cultural Heritage Resources Management in USAT Liberty, Tulamben, Bali, Indonesia. Master thesis Leiden University.

Malpas, J. (2007). Cultural Heritage in the Age of New Media. In Y. E. Kalay, T. Kvan, \& J. Affleck (Eds.), New Heritage: New Media and Cultural Heritage (pp. 13-26). New York: Routledge.

Murphy, J. W. (2014). Community-Based Interventions, International Perspectives on Social Policy, Administration, and Practice. New York: Springer.

Mutema, G. (2003). Phenomenology, hermeneutics, and the study of indigenous knowledge systems. Indilinga: African Journal of Indigenous Knowledge Systems, 2(1), 81-88.

Ongirwalu, H., \& Jonathans, H. (2014). Melacak Jejak-Jejak Sang Pembebas: Dari Jemaat Masehi ke GPIB Jemaat "Immanuel" Depok. Jakarta: Gunung Mulia.

Pojoh, I. H. E., Sulistyowati, D., Nugraha, A., \& Caesario, D. (2015).. Sistem Informasi Arkeologi: Pangkalan Data Berbasis Daring untuk Perekaman Data Artefak Tembikar dan Keramik di Kawasan Percandian Muarajambi. Amerta, 33(2), 77-84.

Prasidha, I., \& Martokusumo, W. (2014). Modernity and Transformation of the Architecture of Depok City, Indonesia. International Journal of Built Environment and Sustainability, 1(1), 57-62.

Robin, B. (2006). The Educational Uses of Digital Storytelling. In C. Crawford, R. Carlsen, K. McFerrin, J. Price, R. Weber, \& D. Willis (Eds.), Proceedings of SITE 2006-Society for Information Technology \& Teacher Education International Conference (pp. 709-716). Orlando, Florida, USA: Association for the Advancement of Computing in Education (AACE).

Rodil, K., \& Rehm, M. (2015). A decade later: Looking at the past while sketching the future of ICH through the Tripartite Digitisation Model. International Journal of Intangible Heritage, 10, 47-60.

Rodil, K., \& Winschiers-Theophilus, H. (2016). Indigenous Storytelling in Namibia: Sketching Concepts for Digitization. In 2015 International Conference on Culture and Computing (Culture Computing) (pp. 80-86). Kyoto: Institute of Electrical and Electronics Engineers (IEEE).

Rodil, K., \& Winschiers-Theophilus, H. (2018). Why Is She Naked?: An iterative refinement of the digitisation of ICH with the OvaHimba tribe in Namibia. International Journal of Intangible Heritage, 13, 143-154.

Sitokdana, M. N. N. (2015). Digitalisasi Kebudayaan di Indonesia. In Seminar Nasional Teknologi Informasi dan 
Komunikasi 2015. Yogyakarta: Fakultas Teknologi Industri Universitas Atma Jaya.

Tanaamah, A. R., \& Wenas, M. R. (2014). Javanese Culture Digitalization in a Knowledge Management Framework at Kasunanan Surakarta Palace. IJCSI International Journal of Computer Science Issues, 11(3), 125-133.

UNESCO. (2003). Charter on the Preservation of Digital Heritage. Paris: UNESCO. 